\title{
Monitoring and modeling slope dynamics in an Alpine watershed - a combined approach of soil science, remote sensing and geomorphology
}

\author{
F. Neugirg ${ }^{1}$, A. Kaiser ${ }^{2}$, M. Schindewolf ${ }^{2}$, M. Becht ${ }^{1}$, J. Schmidt ${ }^{2}$, and F. Haas ${ }^{1}$ \\ ${ }^{1}$ Department of Physical Geography, Catholic University of Eichstätt-Ingolstadt, Eichstätt, Germany \\ ${ }^{2}$ Soil and Water Conservation Unit, Technical University Bergakademie Freiberg, Freiberg, Germany \\ Correspondence to: F. Neugirg (f.neugirg@ku.de), A. Kaiser (andreas.kaiser@tbt.tu-freiberg.de)
}

Received: 17 March 2015 - Accepted: 17 March 2015 - Published: 12 June 2015

\begin{abstract}
Steep and unvegetated slopes in mountainous areas play an important role in erosion research as they deliver large quantities of sediments to the lowlands. However, their complex hydrological process combinations are challenging for any modelling and forecasting intention. Due to its high morphodynamic activity the Lainbach valley in southern Bavaria, Germany, has repeatedly been subject to studies on erosional processes. We present a further developed approach of physically based erosion modelling on strongly inclined and heavily dissected slopes. Model parameters were spatially and temporally distributed and a statistical model was tested to compare both findings to a previous study in the same catchment on a different slope. High resolution surface models from laser scans served as validation for the modelling results and for monitoring soil loss. Especially an adjustment of hydraulic roughness values improved the results, whereas rill hydraulics demand further investigation for future model development. The study at hand focusses on the summer period and reveals adequate modelling results (98.4\% agreement in volume loss) with regard to the slope's non-stationary behaviour but leaves room for improvement for the winter period.
\end{abstract}

\section{Introduction}

Fluvial erosion on sparsely or unvegetated hillslopes is the major sediment source in the Lainbach valley, located in the northern Alps. Several studies have focussed on acting geomorphological processes at these slopes (Becht, 1986; Kaiser et al., 2014; Neugirg et al., 2014; Wetzel, 1992; Schindewolf et al., 2015). This study aims to improve modelled sediment yields with regard to a first attempt on a neighbouring slope and to further develop both a statistical and a physically based erosion model for their application in Alpine conditions.

Terrestrial laser scanning (TLS) also referred to as terrestrial LiDAR (Light Detection And Ranging) has become a well established tool in geoscientific studies. Especially detection of surface changes in hydrological studies (Baewert and Morche, 2014; Milan et al., 2007) or volumetric changes due to mass movements, like debris flows (Bull et al., 2010; Schürch et al., 2011) and rock falls (Abellán et al., 2011;
Haas et al., 2012b) can be acquired with a drastically increased spatial resolution compared to previously used geomorphological measurement tools, like erosion pins (Della Seta et al., 2009) or sediment traps (Haas, 2008). Besides the spatial resolution, the contact-less acquisition of data is another major advantage of LiDAR. In the present study we repeatedly produced LiDAR data to measure surface changes and soil losses and compare these results to our erosion model predictions for the same period.

Soil erosion models improved during the last decades and are helpful in research as well as on the administrative level. Concurrently with the increased experimental effort in erosion research (Iserloh et al., 2013; Wirtz et al., 2013; Castillo et al., 2012) a gain in computing and data acquisition capacities allowed for higher resolution terrain models produced either by TLS or by SfM procedures. In this regard, physically based erosion models might offer a powerful tool for process differentiation of steep slope dynamics. Although the physically based EROSION 3D soil loss simulation model 


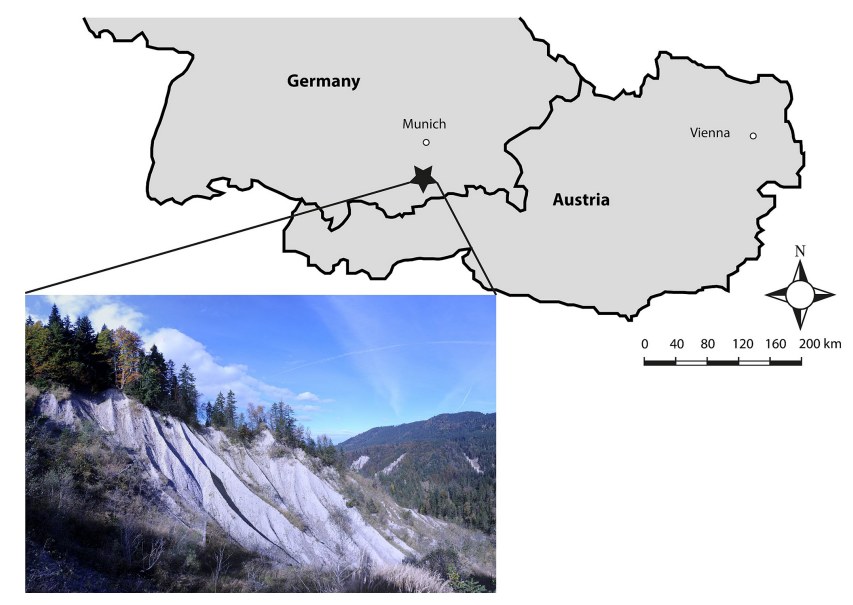

Figure 1. The study area is located in the Lainbach valley catchment in the Northern Bavarian Alps, Germany.

has been extensively validated (Starkloff and Stolte, 2014; Jetten et al., 1999, 2003; Defersha et al., 2012), applications on steep slopes go along with new challenges. The high spatial heterogeneity related with a limited accessibility of such areas is hindering parameter identification prior to model parameterization. Since first parameter identifications succeeded in 2013 including rainfall simulations (Kaiser et al., 2014) model parameterization for the Lainbach valley site became possible. Nevertheless, the natural non-stationarity of the catchment and the different processes during summer and winter were challenging for the model even though it works event based and is sensitive for heavy rainfall and discharge. Strong inclinations trigger processes like rock fall or small-scale mudflows which are not existent on agricultural land, where the model was developed. All rills on the slope are highly ephemeral with a quick response to rainfall and long inactivity during dry conditions which justifies the application of an event based soil loss model.

As a first application of the physical model presented in Schindewolf et al. (2015) showed room for improvement in terms of correct localization of dynamic rill areas and total sums of detachment, the present study successfully tackled these issues. To test the practicability of transferring the model to other areas a comparable slope in the same area with only few distinctions such as exposure and slope length was chosen.

\section{The Lainbach valley catchment}

The Lainbach valley catchment is an alpine mountain catchment in the northern Alps (Fig. 1), which has its highest point at $1801 \mathrm{~m}$ (Benediktenwand). The outlet of the catchment at $\sim 700 \mathrm{~m}$ is located at the town of Benediktbeuern in Upper Bavaria, about $60 \mathrm{~km}$ south of Munich. Although large areas of the catchment are vegetated with mixed forests (Becht and Kopp, 1988), several sparsely vegetated or com- pletely uncovered erosional scars can be found. All of these erosional scars, according to Becht and Kopp (1988), had their maximum spatial extent on aerial photographs from 1959. The erosional scars are situated at local valley fillings that have been the result of several advances of the glacier Isar-Loisach. Becht (1992) mentions a thickness of the valley fillings of $\sim 150 \mathrm{~m}$ for the investigated slopes in this study. Kaiser et al. (2014) supports the assumptions of Wetzel (1992) and revealed very high bulk densities for the hillslopes. The monitored slope in this study is close located to the slope studied in Kaiser et al. (2014), Neugirg et al. (2014, 2015) and Schindewolf et al. (2015). Both slopes show nearly the same average slope gradient, the same height above sea level and the same bulk density of the substrate. Additionally, the precipitation and temperature conditions are comparable, since both slopes are located almost next to each other. The aspect of both slopes and the average slope length is entirely different (Table 1).

\section{Data acquisition and model description}

The results presented in this study are based on two field work campaigns that were carried out on May 2014 and October 2014. The acquisition dates have been chosen to represent the summer period in the best way and that all winterly effects (snow cover during spring, fallen leaves in the rills in autumn) could be minimized.

\subsection{Data acquisition using TLS}

TLS data were acquired using a Riegl LMS Z420i in combination with an on-top mounted Nikon D700 DSLR camera. The DSLR camera allows to colourize the point cloud during post processing for better orientation and filtering procedures. Two (May 2014), respectively three (October 2014) scan positions were used to minimize shadowing effects, due to heavily incised rills and gullies on the slope. The alignment of the different scan positions, as well as the alignment of the different time steps was carried out using permanently fixed tie objects, placed around the slope. For further post processing - e.g. alignment of the point clouds, colouring of the point clouds, vegetation filtering... - we used the software RiSCAN Pro v1.7.9 that comes with the TLS system. Finally processed point clouds were exported and gridded in SAGA GIS/LIS (Rieg et al., 2014) with cell sizes of $10 \times 10 \mathrm{~cm}$. Further details and information concerning the TLS post processing workflow are explained in much more detail in Haas et al. (2011a, 2012a).

In order to quantify and analyse surface changes, we applied a filtering method according to. Using the inaccuracy of the measuring device and a statistical $t$ test, only significant changes were analysed. The level of detection (LoD) under a $95 \%$ confidence interval was calculated as $5.54 \mathrm{~cm}$

$$
\mathrm{LoD}=t_{\text {crit }} \sqrt{\delta_{1}^{2}+\delta_{2}^{2}}
$$


Table 1. Topographical data and relief parameter.

\begin{tabular}{|c|c|c|}
\hline & $\begin{array}{l}\text { Parameters for the hillslope } \\
\text { presented in this study }\end{array}$ & $\begin{array}{l}\text { Parameters for the hillslope } \\
\text { presented in Schindewolf } \\
\text { et al. }(2015) \text { and Neugirg } \\
\text { et al. }(2014,2015)\end{array}$ \\
\hline height above s.l. in & $\sim 1000 \mathrm{~m}$ & $\sim 1000 \mathrm{~m}$ \\
\hline aspect of the slope & East & West \\
\hline average slope length & $35 \mathrm{~m}$ & $8 \mathrm{~m}$ \\
\hline average slope gradient & $50^{\circ}$ & $51^{\circ}$ \\
\hline bulk density of substrate & $1930 \mathrm{~kg} \mathrm{~m}^{-3}$ & $1930 \mathrm{~kg} \mathrm{~m}^{-3}$ \\
\hline
\end{tabular}

More detailed information on the application of the statistical $t$ test are explained in Lane et al. (2003), Brasington et al. (2003), Wheaton et al. (2009), and Neugirg et al. (2015).

\subsection{Erosion 3D - physically based erosion modelling under alpine conditions}

To account for the non-stationary nature of our research area a physically and event based erosion model was chosen to depict the multitude of processes adequately. All mathematical and physical equations incorporated in the soil loss model are beyond the scope of this article but are accessible in Schindewolf and Schmidt (2012). EROSION 3D requires basic parameters such as rainfall, a digital terrain model and soil structural data. Furthermore, additional inputs such as the hydraulic surface roughness and soil resistance to erosion are derived from simulated rainfall experiments. As the model was developed for and is usually applied on agricultural sites data is commonly accessible from official sources. Nevertheless, for the Lainbach valley conditions differed in various aspects from the above: smaller size of the research area, stronger inclination, higher bulk densities combined with large gravel quantities and - for the winter period snow influences and freeze-thaw cycles. Resulting from the above and as a prerequisite for decent modelling results, adequate data needed to be generated specifically for the site. The terrain data was derived as a by-product from the TLS monitoring, data on soil behaviour to heavy rainfall was produced with an artificial rainfall simulator and on-site sampling and can be accessed in Kaiser et al. (2014). Meteorological data input was ensured by a climate station at the slope with rainfall data in 15 min steps (Fig. 2). The precipitation data was also used for extracting wet and dry soil conditions in advance to a subsequent erosive rain event. The latter were identified by filtering for events with more precipitation than $0.25 \mathrm{~mm} \mathrm{~min}^{-1}$ or $10 \mathrm{~mm} \mathrm{~h}^{-1}$.

As shown in Schindewolf et al. (2015) the transfer of the model to alpine conditions was accompanied by various challenges which could partially be resolved in the aftermath of the initial application for the summer period. Especially the roughness values were corrected by data from rill flushing experiments along with tracer measurements. A levelling

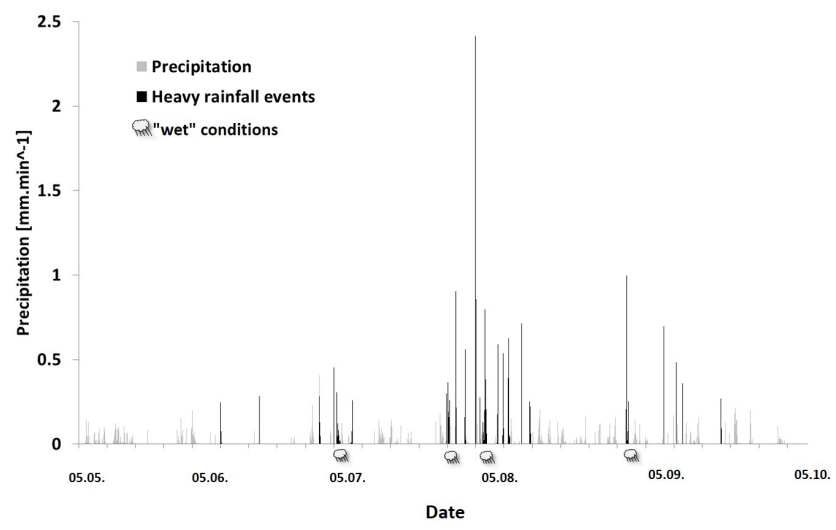

Figure 2. Precipitation for the monitored and modeled period with the filtered events and wet soil conditions for model parametrization.

of surface irregularities in the rills by runoff was accounted for by adjusting roughness values from 0.012 for the overall slope to 0.0365 (dry) and 0.0235 (wet) for interrill areas respectively 0.0245 (dry) and 0.0095 (wet) for the rills.

\subsection{Statistical-based erosion modelling using the sediment contributing area}

In order to model fluvial erosion in alpine catchments, Haas (2008) and Haas et al. (2011b) developed a rule-based statistical model. Sediment delivery was measured by using erosion traps in channels. These sediment delivery rates were correlated with the size of the sediment contributing area (SCA) upstream of the related erosion trap. Both values showed positive correlations on a log-log plot. Neugirg et al. (2014) showed that an adaption from catchment to hillslope scale provides promising results. Furthermore the model was expanded with a random sampling of the chosen virtual traps in order to get a greater variance in the sizes of the SCA (Neugirg et al., 2015). For this study, measured erosion values for the five month summer period were routed downslope in SAGA GIS/LIS using the module "Catchment Area (parallel)". Since the entire slope is without hindering vegetation and it is steep enough, the rule-based approach for the 


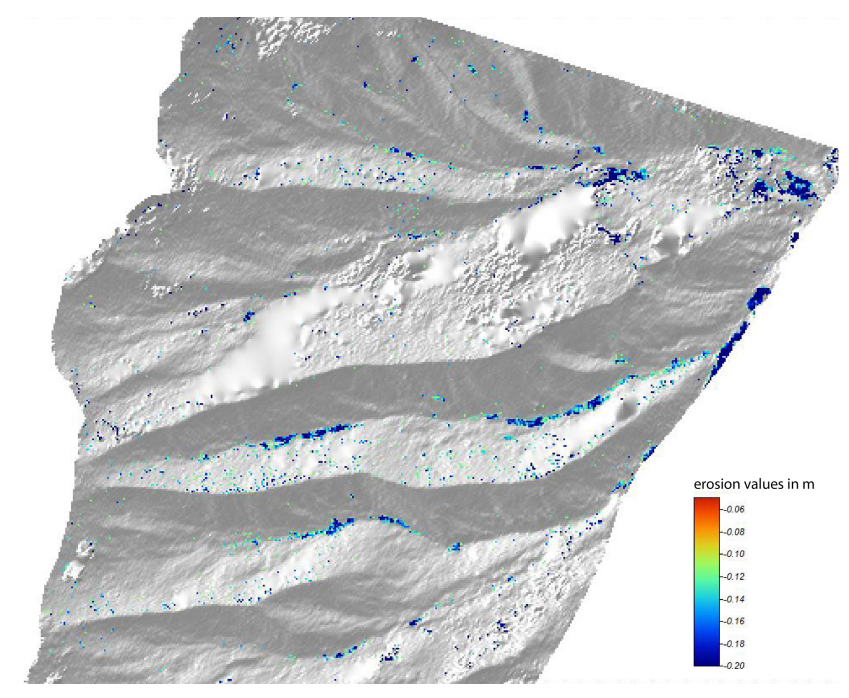

Figure 3. Surface changes from TLS data.

extraction of the SCA could be ignored. Instead the normal hydrological catchments were used. In order to expand the statistical analysis from Neugirg et al. (2014) we allowed the sampling algorithm to pick any grid cell within a rill/channel. We used a random sampling to pick one grid cell for each rill/channel. In terms of statistical independence it is important to only pick one cell per rill. Otherwise lower lying cells in a rill are autocorrelated with the other cells as they are directly independent from the upwards lying cells (downslope routing of the surface changes). Therefore we correlated the sediment yield and the size of the hydrological catchment for 14 values and applied a linear equation according to the sampled values. The sampling was repeated 100 times, which leads to 100 different linear equations. The linear equations are based on the Eq. (2):

log. sediment yield $=$ intercept + slope $\cdot$ SCA

\section{Results}

\subsection{Measured surface changes using TLS}

The erosion of all grid cells with significant erosion values has a mean of $21 \mathrm{~cm}$ and a standard deviation of $18 \mathrm{~cm}$. Erosion is mainly focussed within the rills and at the bottom of the channels (Fig. 3). These areas show consistent and coherent greater erosional areas. Some smaller singular erosion patches are also at the slopes and channel walls. Furthermore almost no erosion can be detected at the channel heads. The main erosion hot spots are from about $1 / 3$ of the channel length down to the slope foot.

\subsection{E3d Model results}

For the summer period a maximum surface lowering of $51 \mathrm{~cm}$ at a mean value of $15 \mathrm{~cm}$ at a standard deviation of

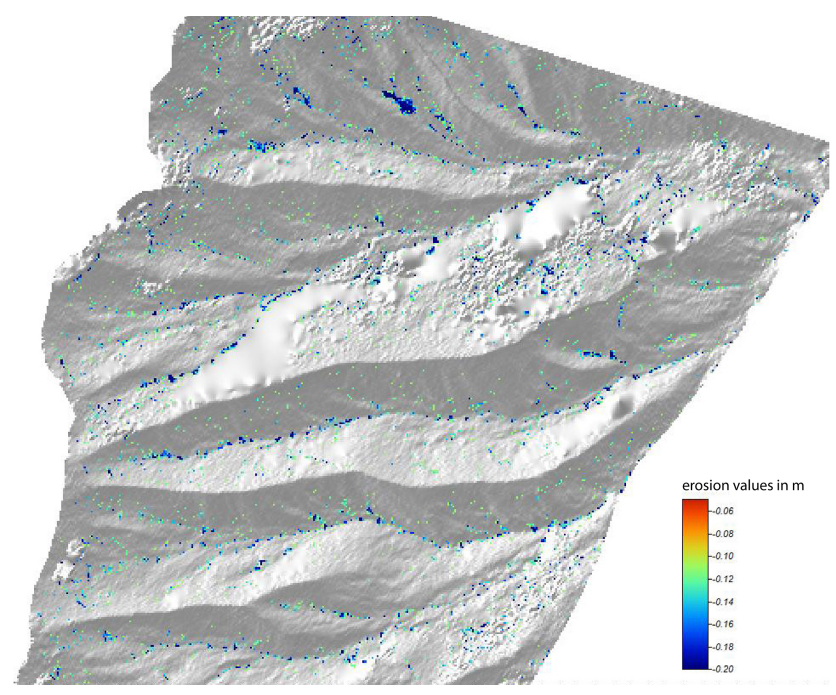

Figure 4. Modelling results from E3d.

$4.77 \mathrm{~cm}$. Negligible deposition occurred in a few cells on the slope bottom whilst the larger quantity of soil is transported beyond the area of the investigated slope (Fig. 4). With regard to a pattern in the modelled soil loss the rills show concentrations of higher erosion value. Nevertheless, areas on the sidewalls of the incisions also show contributing rilling forms. Compared to the TLS results the proportion of the sidewall effects is higher, while rill incision in the large rills is underestimated. Furthermore, a tendency of higher changes towards to upper (western) part of the slope in the model contradicts the TLS data, which reveals major incisions in the lower (eastern) areas.

\subsection{Statistical-based erosion model results}

The model results show a positive correlation between sediment contributing area and the sediment yield (Fig. 5, left side). The goodness of the correlation is expressed as $R^{2}$ for each of the 100 linear equations (Table 3 ). $R^{2}$ values are distributed from 0.26 to 0.63 with a median of 0.48 . In order to achieve a better comparability, intercept and slope of the linear equations was averaged for one month. Intercept values show a range from $0.336-0.531$ with a median of 0.432 . Slope values vary between 0.068 and 0.191 with a median of 0.132 .

\section{Discussion}

Considering the results presented in Schindewolf et al. (2015) the spatial and temporal distribution of manning's $n$ roughness values showed an improved reproducibility of the summerly slope processes. Furthermore, it was mandatory to also apply the significant changes (LoD) of the TLS scans of the modelling results from EROSION 3D. As erosion induced surface changes are frequently scaled in a mil- 

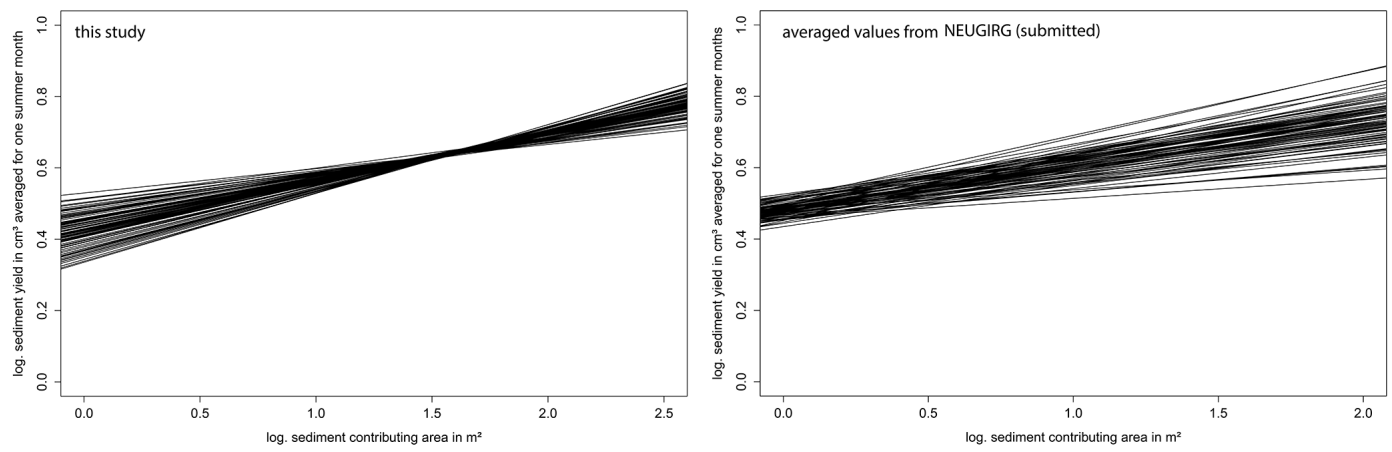

Figure 5. Model results of the statistical-based erosion model. Averaged values for one month for this study (left) and for the study by Neugirg et al. (2015) (right).

Table 2. Surface changes acquired with TLS (left) and E3D (right).

\begin{tabular}{cccccccc}
\hline \multicolumn{2}{c}{ TLS } & & & \multicolumn{3}{c}{ E3D } \\
\cline { 1 - 2 } \cline { 5 - 7 } $\begin{array}{c}\text { no. of cells } \\
\text { with significant } \\
\text { surface change }\end{array}$ & $\begin{array}{c}\text { mean of } \\
\text { change }\end{array}$ & $\begin{array}{c}\text { Volume } \\
\left(\mathrm{m}^{3}\right)\end{array}$ & & $\begin{array}{c}\text { no. of cells } \\
\text { with significant } \\
\text { surface change }\end{array}$ & $\begin{array}{c}\text { mean of } \\
\text { change }\end{array}$ & $\begin{array}{c}\text { Volume } \\
\left(\mathrm{m}^{3}\right)\end{array}$ \\
\hline 3785 & $-0.22 \mathrm{~m}$ & 8.523 & & 5537 & $-0.15 \mathrm{~m}$ & 8.665 \\
\hline
\end{tabular}

Table 3. Results from the statistical based erosion model for one month.

\begin{tabular}{lrrrlrrr}
\hline $\begin{array}{l}\text { SCA } \\
\text { this study }\end{array}$ & Intercept & Slope & $R^{2}$ & $\begin{array}{l}\text { SCA (Neugirg } \\
\text { et al., 2015) }\end{array}$ & Intercept & Slope & $R^{2}$ \\
\hline min & 0.336 & 0.068 & 0.26 & min & 0.448 & 0.052 & 0.12 \\
median & 0.432 & 0.132 & 0.48 & median & 0.482 & 0.116 & 0.48 \\
max. & 0.531 & 0.191 & 0.63 & max & 0.519 & 0.183 & 0.89 \\
\hline
\end{tabular}

limetre range, TLS results are questionable at the lower end of the scale. Thus, the modelling could be adduced to adequately complement the laserscan in a way that also microtopographical changes are included in the overall erosion budget. However, for reason of comparability between TLS and EROSION 3D a LoD of $5.54 \mathrm{~cm}$ was applied on both methodologies.

Analysing the spatial distribution of the soil loss illustrates differences between both applications especially in the rills. The adjusted roughness values for dry and wet conditions interacting with a fitted spatial differentiation of rill and interrill areas improved the pattern but also leaves potential for further advancement. As the initial model application was limited to agricultural sites during model parametrisation, sheet flow played an important role. This could be a reason for more detachment on the rather even sidewall parts of the rills and less erosion in the rill's depression lines when compared to the TLS data. As rill hydraulics are not yet implemented in the model the active parts on the laser scans, which are more or less limited to the lower regions of the rills, are less active in the EROSION 3D results. This is due to the flow reaching transport capacity which hinders further detachment while accumulated runoff, undercuttings and turbulent flow might further boost erosion inside the rills.

The model results of the statistical-based erosion model show medium to good correlations for $50 \%$ of the samplings. Half of the models show higher $R^{2}$ values than 0.48 . This is exactly the same median $R^{2}$ value Neugirg et al. (2015) showed for another smaller slope in the same catchment area (Table 3, Fig. 5). However, the range of $R^{2}$ is much smaller than the values for the previous study. In contrast, intercept and slope values are in very good agreement with the values from Neugirg et al. (2015). This agreement is very promising as it implies the applicability of the model from one slope to another under same conditions (similar substrate, precipitation) in one catchment area. Resulting differences between this (2014) and the previous study (2009) might be due to different precipitation data, contrary aspect of the slope and differences in the length of the slope. But these differences show much less discrepancies than the comparison of this method for study areas with different substrate and climatic settings (Neugirg et al., 2015). 


\section{Conclusions}

The presented results (Table 2) do show progress in soil loss modelling for the research area for fluvial erosion during the summer, but also leave room for improvement in spatial distribution. By ignoring the winter period we avoided the phase of highest activity in the catchment and thus excluded several variables that favour non-stationarity. This was a result of limitations in modelling that became evident when comparing TLS-measured erosion rates to modelled ones for the winter period analysed in Schindewolf et al. (2015). Future research will tackle the winter period including freeze-thaw cycles, solifluction and snow-triggered processes.

Rill processes are not yet implemented in the model and need to be tackled for a suitable reproduction from the spatial distribution point of view. Nevertheless, an adjustment of roughness values led to better results in comparison to the TLS data. While the grid resolution increased rapidly from $20 \times 20 \mathrm{~m}^{2}$ to now $10 \times 10 \mathrm{~cm}^{2}$ the model parameters do not yet meet the demands of the new high resolution environment. Individual processes need to be measured and analysed more precisely after the change in scale with rill behaviour and hydraulics being of major importance. Regarding the fact that the modelling approach was implemented to reproduce and thus forecast soil losses for comparable slopes, the significant agreement between total soil losses from both methods is a step forward.

Predictions for future erosion volumes can not be made yet. A first step towards a prediction is the analysis and quantification of each single geomorphological process and its contribution to the annual sediment budget. First promising results and a clear differentiation between winter and summer processes show the studies of Schindewolf et al. (2015) and Neugirg et al. (2015). Nevertheless, a separation of all processes is necessary. Therefore, for future studies a decrease of the level of detection is absolutely crucial. Especially very small processes and minor surface changes that often occur, even during lower intensity rain falls, cannot be detected with the present LoD calculations.

Acknowledgements. This work was supported by the German Research Foundation (DFG grant numbers: HA5740/3-1, SCHM1373/8-1). Furthermore the authors want to thank Alena Huber and Paula Hilger for help with the precipitation data as well as the students Manuel Stark, Christian Böhm and Nico Schultze for their valuable help during field work and in the laboratory.

\section{References}

Abellán, A., Vilaplana, J. M., Calvet, J., García-Sellés, D., and Asensio, E.: Rockfall monitoring by Terrestrial Laser Scanning - case study of the basaltic rock face at Castellfollit de la Roca (Catalonia, Spain), Nat. Hazards Earth Syst. Sci., 11, 829-841, doi:10.5194/nhess-11-829-2011, 2011.
Baewert, H. and Morche, D.: Coarse sediment dynamics in a proglacial fluvial system (Fagge River, Tyrol), Geomorphology, 218, 88-97, doi:10.1016/j.geomorph.2013.10.021, 2014.

Becht, M.: Die Schwebstofführung der Gewässer im Lainbachtal bei Benediktbeuern/Obb., Dissertation, München, 1986.

Becht, M. (Ed.): Contributions to the Excursions during the International Conference "Dynamics and Geomorphology of Mountain Rivers", Geobuch-Verlag, München, 1992.

Becht, M. and Kopp, M.: Aktuelle Geomorphodynamik in einem randalpinen Wildbacheinzugsgebiet und deren Beeinflussung durch die Wirtschaftsweise des Menschen, 46. Deutscher Geographentag München. Tagungsberichte und wiss. Abhandlungen, 526-534, 1988.

Brasington, J., Langham, J., and Rumsby, B.: Methodological sensitivity of morphometric estimates of coarse fluvial sediment transport, Geomorphology, 53, 299-316, doi:10.1016/S0169555X(02)00320-3, 2003.

Bull, J. M., Miller, H., Gravley, D. M., Costello, D., Hikuroa, D. C. H., and Dix, J. K.: Assessing debris flows using LIDAR differencing: 18 May 2005 Matata event, New Zealand, Geomorphology, 124, 75-84, doi:10.1016/j.geomorph.2010.08.011, 2010.

Castillo, C., Pérez, R., James, M. R., Quinton, J. N., Taguas, E. V., and Gómez, J. A.: Comparing the Accuracy of Several Field Methods for Measuring Gully Erosion, Soil Sci. Soc. Am. J., 76, 1319, doi:10.2136/sssaj2011.0390, 2012.

Defersha, M. B., Melesse, A. M., and McClain, M. E.: Watershed scale application of WEPP and EROSION 3D models for assessment of potential sediment source areas and runoff flux in the Mara River basin, Kenya, Catena, 95, 63-72, doi:10.1016/j.catena.2012.03.004, 2012.

Della Seta, M., Del Monte, M., Fredi, P., and Lupia Palmieri, E.: Space-time variability of denudation rates at the catchment and hillslope scales on the Tyrrhenian side of Central Italy, Geomorphology, 107, 161-177, doi:10.1016/j.geomorph.2008.12.004, 2009.

Haas, F.: Fluviale Hangprozesse in Alpinen Einzugsgebieten der Nördlichen Kalkalpen: Quantifizierung und Modellierungsansätze, Dissertation, 2008.

Haas, F., Heckmann, T., Becht, M., and Cyffka, B.: Ground-based laserscanning - a new method for measuring fluvial erosion on steep slopes, in: GRACE, remote sensing and ground-based methods in multi-scale hydrology: Proceedings of the symposium JHS01 [entitled: GRACE, remote sensing and groundbased methods in multi-scale hydrology] held during the IUGG GA in Melbourne (28 June-7 July 2011), edited by: Hafeez, M. M., IAHS publication, 343, IAHS Publ, Wallingford, 163-168, 2011 a.

Haas, F., Heckmann, T., Wichmann, V., and Becht, M.: Quantification and Modeling of Fluvial Bedload Discharge from Hillslope Channels in two Alpine Catchments (Bavarian Alps, Germany), Z. Geomorph. N.F. Suppl., 55, 147-168, 2011 b.

Haas, F., Heckmann, T., Hilger, L., and Becht, M.: Quantification and modelling of debris flows in the proglacial area of the Gepatschferner, Austria, using ground-based LiDAR, in: Erosion and Sediment Yields in the Changing Environment, International Association of Hydrological Sciences, Erosion and Sediment Yields in the Changing Environment, edited by: Collins, A. L., Golosov, V., Horowitz, A. J., Lu, X., Stone, M., and Walli, D. 
E. (IAHS), Chengdu, China, 11-15 October, IAHS publication, 356, IAHS Press, Wallingford, 293-302, 2012a.

Haas, F., Heckmann, T., Wichmann, V., and Becht, M.: Runout analysis of a large rockfall in the Dolomites/Italian Alps using LIDAR derived particle sizes and shapes, Earth Surf. Proc. Land., 37, 1444-1455, doi:10.1002/esp.3295, 2012b.

Iserloh, T., Ries, J., Arnáez, J., Boix-Fayos, C., Butzen, V., Cerdà, A., Echeverría, M., Fernández-Gálvez, J., Fister, W., Geißler, C., Gómez, J., Gómez-Macpherson, H., Kuhn, N., Lázaro, R., León, F., Martínez-Mena, M., Martínez-Murillo, J., Marzen, M., Mingorance, M., Ortigosa, L., Peters, P., Regüiés, D., RuizSinoga, J., Scholten, T., Seeger, M., Solé-Benet, A., Wengel, R., and Wirtz, S.: European small portable rainfall simulators: A comparison of rainfall characteristics, Catena, 110, 100-112, doi:10.1016/j.catena.2013.05.013, 2013.

Jetten, V., de Roo, A., and Favis-Mortlock, D.: Evaluation of fieldscale and catchment-scale soil erosion models, Catena, 37, 521541, 1999.

Jetten, V., Govers, G., and Hessel, R.: Erosion models: quality of spatial predictions, Hydrol. Process., 17, 887-900, doi:10.1002/hyp.1168, 2003.

Kaiser, A., Neugirg, F., Schindewolf, M., Haas, F., and Schmidt, J.: Simulation of rainfall effects on sediment transport on steep slopes in an Alpine catchment, IAHS Publ. - Proceedings of a symposium held in New Orleans, Louisiana, USA, 11-14 December 2014, 367, 43-50, 2014.

Lane, S. N., Westaway, R. M., and Murray Hicks, D.: Estimation of erosion and deposition volumes in a large, gravel-bed, braided river using synoptic remote sensing, Earth Surf. Proc. Land., 28, 249-271, doi:10.1002/esp.483, 2003.

Milan, D. J., Heritage, G. L., and Hetherington, D.: Application of a 3D laser scanner in the assessment of erosion and deposition volumes and channel change in a proglacial river, Earth Surf. Proc. Land., 32, 1657-1674, doi:10.1002/esp.1592, 2007.

Neugirg, F., Kaiser, A., Huber, A. C., Schindewolf, M., Heckmann, T., Schmidt, J., Becht, M., and Haas, F.: Using terrestrial LiDAR data to quantify, analyse and model different processes in hillslope development, CATENA, submitted, 2015.

Neugirg, F., Kaiser, A., Schmidt, J., Becht, M., and Haas, F.: Quantification, Analysis and Modelling of soil erosion on steep slopes using LiDAR and aerial photos, IAHS Publ. - Proceedings of a symposium held in New Orleans, Louisiana, USA, 11-14 December 2014, 367, 51-58, 2014.
Rieg, L., Wichmann, V., Rutzinger, M., Sailer, R., Geist, T., and Stötter, J.: Data infrastructure for multitemporal airborne LiDAR point cloud analysis - Examples from physical geography in high mountain environments, Computers, Environ. Urban Syst., 45, 137-146, doi:10.1016/j.compenvurbsys.2013.11.004, 2014.

Schindewolf, M., Kaiser, A., Neugirg, F., Richter, C., Haas, F., and Schmidt, J.: Seasonal erosion patterns under alpine conditions: benefits and challenges of a novel approach in physically based soil erosion modeling, Z. Geomorph. N.F. Suppl., in press, 2015.

Schindewolf, M. and Schmidt, J.: Parameterization of the EROSION 2D/3D soil erosion model using a small-scale rainfall simulator and upstream runoff simulation, Catena, 91, 47-55, doi:10.1016/j.catena.2011.01.007, 2012.

Schürch, P., Densmore, A. L., Rosser, N. J., Lim, M., and McArdell, B. W.: Detection of surface change in complex topography using terrestrial laser scanning: application to the Illgraben debris-flow channel, Earth Surf. Proc. Land., 36, 1847-1859, doi:10.1002/esp.2206, 2011.

Starkloff, T. and Stolte, J.: Applied comparison of the erosion risk models EROSION 3D and LISEM for a small catchment in Norway, Catena, 118, 154-167, doi:10.1016/j.catena.2014.02.004, 2014.

Wetzel, K.-F.: Abtragsprozesse an Hängen und Feststoffführung der Gewässer. Dargestelllt am Beispiel der pleistozänen Lockergesteine des Lainbachgebietes (Benediktbeuern/Obb.), Münchener Geographische Abhandlungen B, 17, Geobuch-Verlag, München, 188 pp., 1992.

Wheaton, J. M., Brasington, J., Darby, S. E., and Sear, D. A.: Accounting for uncertainty in DEMs from repeat topographic surveys: improved sediment budgets, Earth Surf. Proc. Land., 35, 136-156, doi:10.1002/esp.1886, 2009.

Wirtz, S., Seeger, M., Zell, A., Wagner, C., Wagner, J.-F., Ries, J. B., and Magar, V.: Applicability of Different Hydraulic Parameters to Describe Soil Detachment in Eroding Rills, PLoS ONE, 8, e64861, doi:10.1371/journal.pone.0064861, 2013. 